Mu'jam al-mațbū'āt al-'arabiyya fì šibh al-qārra alHindiyya al-Bākistāniyya mundu duHul al-mațba'a ilayhā hatta 'ām 1980 / Catalogue of Arabic Books Printed in Indo-Pakistan Subcontinent (since coming of Press here down to 1980 A.D.), Riyadh, Bibliothèque Nationale du Roi Fahd, 2000, Tome I, 618 p., index. [Les livres arabes imprimés dans le sous-continent indo-pakistanais (depuis la création de l'imprimerie dans la région jusqu'à 1980)]

\title{
Arif Naushahi
}

\section{(2) OpenEdition}

\section{Édition électronique}

URL : http://journals.openedition.org/abstractairanica/35039

DOI : 10.4000/abstractairanica.35039

ISSN : 1961-960X

Éditeur :

CNRS (UMR 7528 Mondes iraniens et indiens), Éditions de l'IFRI

\section{Édition imprimée}

Date de publication : 15 mai 2002

ISSN : 0240-8910

Référence électronique

Arif Naushahi, « Mu'jam al-mațbū'āt al-'arabiyya fi šibh al-qārra al-Hindiyya al-Bākistāniyya mundu duhul almațba'a ilayhā hatta 'ām 1980 / Catalogue of Arabic Books Printed in Indo-Pakistan Subcontinent (since coming of Press here down to 1980 A.D.), Riyadh, Bibliothèque Nationale du Roi Fahd, 2000, Tome I, 618 p., index. [Les livres arabes imprimés dans le sous-continent indo-pakistanais (depuis la création de l'imprimerie dans la région jusqu'à 1980)] », Abstracta Iranica [En ligne], Volume 23 | 2002, document 1, mis en ligne le 08 février 2010, consulté le 25 septembre 2020. URL : http:// journals.openedition.org/abstractairanica/35039; DOI : https://doi.org/10.4000/abstractairanica. 35039

Ce document a été généré automatiquement le 25 septembre 2020. 
Mu'jam al-mațbū'āt al-'arabiyya fi šibh al-qārra al-Hindiyya al-Bākistāniyya mundu duHul al-mațba'a ilayhā hatta 'ām 1980 / Catalogue of Arabic Books Printed in Indo-Pakistan Subcontinent (since coming of Press here down to 1980 A.D.), Riyadh, Bibliothèque Nationale du Roi Fahd, 2000, Tome I, 618 p., index. [Les livres arabes imprimés dans le sous-continent indo-pakistanais (depuis la création de l'imprimerie dans la région jusqu'à 1980)]

Arif Naushahi

Cet ouvrage est un bref répertoire des livres arabes publiés en Inde et au Pakistan (ainsi qu'en Birmanie et à Singapour). La création de l'imprimerie en Inde remonte à 1550, date à laquelle les Portugais sont entrés au sud de l'Inde. Par la suite, la Compagnie des Indes Orientales (East India Company) accélère la diffusion de cette technique au Bengale. Au $19^{\mathrm{e}} \mathrm{s}$., le sous-continent indien devient le centre de la publication des livres 
arabes et persans. Ce catalogue, rédigé en arabe, répertorie les livres par auteur depuis le premier ouvrage arabe publié dans le sous-continent (Al-Serājī, Sajāvandī, Calcutta, 1206/1793) jusqu'aux publications datant de 1980. Le catalogue mentionne plusieurs ouvrages contenant une traduction et des notes en persan : le persan était en effet le vecteur vers l'arabe pour les habitants du sous-continent. On peut regretter l'absence d'un index thématique qui aurait pu faciliter le repérage d'un ouvrage sur un thème précis.

INDEX

Thèmes : 1.1. Bibliographie

\section{AUTEURS}

ARIF NAUSHAHI

Islamabad - Pakistan 